\title{
Producing Plant Material at Intermediate Grafted Apple
}

\author{
Radu BARASCU ${ }^{1,2}$, Liliana Aurelia BADULESCU ${ }^{1}$, Dorel HOZA ${ }^{1 *}$ \\ ${ }^{1}$ University of Agronomic Sciences and Veterinary Medicine of Bucharest, Faculty of Horticulture, 59 Marasti Blvd, 011464, Bucharest, \\ Romania; lilib_20@yahoo.com;dorel.hoza@gmail.com ("correspondingauthor) \\ ${ }^{2}$ Valcea Plant nursery, 343 A, Mihaesti, Vâlcea County, Romania; barascu_radu@yahoo.com
}

\begin{abstract}
Tree precocity represents an important characteristic that shortens the youth of the tree and influences the cost of maintenance of the orchard during the first years of production. Low vigour rootstocks ensure precocity but do not always ensure a good ramification and are more demanding in terms of culture conditions. Testing the way apple tree behaves using seven varieties ('Pinova', 'Sirius', 'Mutsu', 'GoldRush', 'Mars', 'Karneval' and 'Topaz') grafted in eight combinations out of which four with an intermediary stock showed different reactions determined by the rootstock and by the intermediary itself regarding tree height, capacity to form branches of fruit and fruit buds. Tree height was influenced by the vigour of the rootstock; the largest trees were produced using the rootstock 'MM106' while the ' $\mathrm{B}$ ') used as interstem greatly reduced the vigour of the trees grafted on 'A2' and 'MM111'. The ramification capacity depended on the grafting combination; the number of formed branches per tree had values between 0-13.4 depending on the rootstock, the interstem 'B9' having a positive influence on the result. The number of fruit buds formed in the plant nursery without any interventions on the trees was greatly influenced by the grafting interstem, the growth being of over $50 \%$ for all tested combinations. Thus the use of interstems represents an alternative to produce trees with fruit branches in plant nurseries.
\end{abstract}

Keywords: branch of fruit, fruit buds, grafting, precocity, rootstock

\section{Introduction}

The apple tree (Malus domestica Borkh.) is one of the most important fruit growing species cultivated in Romania and worldwide, especially in mild areas, as its fruit can be consumed fresh or used as raw material for the food industry (Cimpoies, 2012). As investments are high the research is focused on solutions to reduce the youth period by using low vigour rootstocks that lead to precocity (Gjamovski and Kiprijanovski, 2011) and produce trees with fruit branches formed in nurseries (Atay and Koyuncu, 2013). The use of low stature rootstocks has technological advantages (Ferree and Rhodus, 1987; Tworkoski and Miller, 2007) but requires good soil, water and fertilizers in large quantities and also a good support system. Samad $e t$ al., (1999), studying the behaviour of four apple tree varieties grafted on three vigorous rootstocks and two grafting interstems, 'M9' and 'M27', noticed that annual branches decreased by $20 \%$, fruit production increased by $30 \%$, fruit size was not influenced and the colour of the fruit intensified starting with the second year of production for the trees with interstem compared to the ones without interstem. The ramification capacity of the trees in the nursery is also influenced by the rootstock and planting distance (Wilson and Jarassamrit, 1994) and can be stimulated by using certain growth regulators (Baldini and Sansavini, 1973; Johann, 1984; Cody et al., 1985; Basak et al., 1993) or by pruning (Preston, 1968; Wertheim, 1978).

Research made by Bărăscu et al. (2016) with the 'Pinova' variety grafted on several rootstocks with and without interstem showed that the rootstock and the interstem influenced fruit quality in terms of size, colour, firmness, soluble dry substance and phenol content. Fruit quality is dependent on the variety and rootstock, while the temperature range and different factors also influences colour and pigment content (Curry 1997; Lazar et al., 2010; Sestras et al. 2010; Belgado-Gallardo et al., 2016; Jakobek and Barron, 2016).

Low vigour rootstocks have the advantage of leading to precocity and productivity but are more demanding in terms of soil quality and require a fertilization-irrigation system in order to ensure the needed water and nutrition for a proper growth. Otherwise nutrition problems can occur (Samouliene et al., 2016). In order to benefit from a proper rooting and also from a reduced tree height a grafting interstem can be used that modifies the morphologic parameters of the tree by reducing the height and the annual growth and by anticipating the formation of fruit buds (Bărăscu and Hoza, 2015). It also increases the production and fruit size (Rato et al., 2008). 
The studies conducted on the influence of the interstem length on the grafted trees parameters proved that the longer interstem $(20 \mathrm{~cm})$ had more impact on precocity and vigour in comparison to the shorter interstem $(10 \mathrm{~cm})$ (Di Vaio et al., 2009).

The aim of the present paper was to determine the influence of the grafting combination on the trees' vigour, respectively height of trees, the capacity of fruit branches and fruit buds formation in plant nursery.

\section{Materials and Methods}

\section{Experimentaldesign}

The experiment was conducted during 2014-2016 at Vâlcea plant nursery, Vâlcea County, Romania, using seven apple varieties: 'Pinova', 'Mars', 'Sirius', 'Mutsu', 'Karneval', 'GoldRush', and 'Topaz', which were grafted on six rootstocks: 'A2', 'M111', 'M9', 'B9', 'M106' and 'Pi80'. The rootstock 'M9', which is currently largely used, ensures a good precocity to varieties, however its rooting is superficial and needs a support system (espalier). In order to obtain trees with good rooting and also with a precocity similar to that of 'M9' two vigorous rootstocks have been introduced in the study ('A2' and 'M111'). To reduce the vigour of the variety the interstem 'B9' has been grafted on them. The behaviour in orchard of the grafted trees obtained through these combinations will be presented in a future paper.

\section{Experimental procedures}

The rootstocks used for grafting met the standard quality conditions in what regards the thickness, number of roots and scion branches of the studied varieties. The grafting process has been conducted in the grafting hall of the nursery at the beginning of March following the bench grafting technique with the use of manual grafting device, "in omega", at roughly $15 \mathrm{~cm}$ high from the collet. The grafting area has been marked with Banfix tape. The grafted trees have been placed in field in accordance to the experimental scheme. Optimum conditions have been provided in field such as watering, fertilization, fitosanitary protection and soil maintenance works. After leaves fell in autumn the trees have been removed and measured in accordance to the data previously forecast. For the grafting combinations where interstem has been used, in the first year the intermediary ' $\mathrm{B} 9$ ' has been grafted on the rootstocks 'A2' and 'M111' and in the following year in March, in field, the overgrafting has been conducted with the analysed varieties at a height of $30 \mathrm{~cm}$ and $40 \mathrm{~cm}$ respectively above the first grafting area using the same manual grafting device.

\section{Plant sampling and biometrical determinations}

The study has been bifactorial. The A factor has been represented by variety and the $\mathrm{B}$ factor has been represented by rootstock. For each grafting combination 30 plants have been used in three replications following the randomized complete block design. The determinations made have showed precocity translated in height of trees and number of fruit branches and fruits buds on each tree.

\section{Statistical analysis}

In order to observe the manner in which the two factors influence the grafted tree the data obtained has been statistically interpreted using the Duncan test. The dependence between the height of the tree and the capacity to produce fruit branches and fruit buds has been highlighted through the calculation of the regression equation and the correlation coefficient.

\section{Results and Discussion}

\section{Influence of grafting combinations on tree height}

The rootstock, through its vigour, has a direct influence on the varieties that are grafted on it and modifies the parameters of the canopy and the production capacity (Karimi and Nowrozy, 2017). The study conducted in plant nursery and also the data from the present paper have showed that the trees from the seven varieties have grown differently in height as it can be observed from Table 1 .

Comparing the influence of the variety and of the rootstock on the vigour, it can be observed very clearly that the rootstock has a great influence on tree height. Out of the eight grafting combinations studied for the seven varieties the rootstock 'MM106' influenced the most tree height, the average height having values of $230 \mathrm{~cm}$. The lowest vigour was recorded for the trees grafted on the rootstock ' $\mathrm{Pi} 80$ ', which was obtained from crossing the rootstock 'M9' with 'M4' and is a rootstock that requires a support system. It is worth noting that two out of the most vigorous rootstocks, 'A2' and 'MM111', were greatly influenced by the interstem 'B9'; tree height for these combinations had values close to the average for the rootstock 'MM111' and slightly higher for ' $\mathrm{A2}$ ', this rootstock being one of the most vigorous rootstock known for the apple tree. The length of the interstem slightly influenced tree height even though the difference was of only $10 \mathrm{~cm}$. For both combinations with 'MM111' and 'A2', the $40 \mathrm{~cm}$ interstem reduced tree height by $9.6 \%$ compared to the $30 \mathrm{~cm}$ interstem. Out of the seven studied varieties 'Mutsu' proved to be the most vigorous in combination with all rootstocks, tree height having values between $270 \mathrm{~cm}$ on the rootstock 'MM111' and $144 \mathrm{~cm}$ on 'PI80'. The lowest height was recorded for the tree of the 'Karneval' variety, one less known in Romania, an autumn-winter variety, disease tolerant, pleasantly coloured and with a very good taste. The values recorded for tree height were between $86 \mathrm{~cm}$ on the rootstock 'PI80' and $211 \mathrm{~cm}$ on 'MM111'. The average values from Table 1 have shown the increasing hierarchy of the influence which the grafting combination has had on the height of the apple tree.

\section{Influence of grafting combination on the formation of fruit branches \\ The capacity to ramify and to form fruit branches is of great} interest in order to produce trees with pre-formed canopy and to accelerate precocity within the orchard. From this point of view the used rootstocks influenced all the varieties but the reaction was different, without performing any summer pruning as shown in Table 2.

The ramification capacity was greatly influenced by the use of the interstem for all varieties and if we were to refer to the average values obtained two groups of varieties would be highlighted: one with a very good ramification capacity 'Pinova,' 'Mars', 'Sirius' and 'Karneval' and one with a lower capacity to ramify - 'Mutsu', 'GoldRush' and 'Topaz'. 
448

Table 1. The influence of the grafting combination on tree height $(\mathrm{cm})$ at some apple varieties in plant nursery

\begin{tabular}{|c|c|c|c|c|c|c|c|c|c|c|c|c|c|c|c|c|c|c|}
\hline \multirow{3}{*}{$\frac{\text { Variety }}{\text { 'Pinova' }}$} & \multicolumn{2}{|c|}{$\begin{array}{c}\text { B9/MM111 } \\
30 \mathrm{~cm}\end{array}$} & \multicolumn{2}{|c|}{$\begin{array}{c}\text { B9/MM111 } \\
40 \mathrm{~cm}\end{array}$} & \multicolumn{2}{|c|}{$\begin{array}{l}\mathrm{B} 9 / \mathrm{A} 2 \\
30 \mathrm{~cm}\end{array}$} & \multicolumn{2}{|c|}{$\begin{array}{l}\mathrm{B} 9 / \mathrm{A} 2 \\
40 \mathrm{~cm}\end{array}$} & \multicolumn{2}{|c|}{ Pi80 } & \multicolumn{2}{|c|}{ MM106 } & \multicolumn{2}{|c|}{ M9 } & \multicolumn{2}{|c|}{ B9 } & \multicolumn{2}{|c|}{ Average } \\
\hline & 162 & $\mathrm{e}$ & 151 & $\mathrm{c}$ & 182 & $\mathrm{~g}$ & 164 & $f$ & 90 & $\mathrm{a}$ & 235 & $\mathrm{~h}$ & 152 & $\mathrm{c}$ & 142 & $\mathrm{~b}$ & \multirow{2}{*}{159.8} & \multirow{2}{*}{ e } \\
\hline & d & & c & & e & & $\mathrm{b}$ & & d & & e & & e & & $\mathrm{b}$ & & & \\
\hline \multirow{2}{*}{ 'Mars' } & 152 & $\mathrm{e}$ & 142 & $\mathrm{c}$ & 170 & $\mathrm{~g}$ & 166 & $f$ & 88 & $\mathrm{a}$ & 223 & $\mathrm{~h}$ & 150 & $\mathrm{~d}$ & 139 & $\mathrm{~b}$ & \multirow{2}{*}{153.8} & \multirow{2}{*}{ b } \\
\hline & $\mathrm{b}$ & & $\mathrm{a}$ & & $\mathrm{b}$ & & $\mathrm{b}$ & & $\mathrm{b}$ & & $\mathrm{d}$ & & $a$ & & $a$ & & & \\
\hline \multirow{2}{*}{ 'Sirius' } & 177 & $\mathrm{e}$ & 171 & $\mathrm{~d}$ & 189 & $\mathrm{~g}$ & 178 & $\mathrm{e}$ & 123 & $\mathrm{a}$ & 255 & $\mathrm{~h}$ & 160 & $\mathrm{c}$ & 156 & $\mathrm{~b}$ & \multirow{2}{*}{176.1} & \multirow[b]{2}{*}{$\mathrm{f}$} \\
\hline & $\mathrm{f}$ & & $\mathrm{f}$ & & $\mathrm{f}$ & & $\mathrm{f}$ & & $\mathrm{f}$ & & $\mathrm{f}$ & & $\mathrm{f}$ & & $\mathrm{f}$ & & & \\
\hline \multirow{2}{*}{ 'Mutsu' } & 192 & $\mathrm{e}$ & 182 & $\mathrm{~d}$ & 204 & $\mathrm{~g}$ & 196 & $\mathrm{f}$ & 144 & $\mathrm{a}$ & 270 & $\mathrm{~h}$ & 167 & $\mathrm{~b}$ & 166 & $\mathrm{~b}$ & \multirow{2}{*}{190.1} & \multirow[b]{2}{*}{$\mathrm{g}$} \\
\hline & $\mathrm{g}$ & & $\mathrm{g}$ & & $\mathrm{g}$ & & $\mathrm{g}$ & & $\mathrm{g}$ & & $\mathrm{g}$ & & $\mathrm{g}$ & & $\mathrm{g}$ & & & \\
\hline \multirow{2}{*}{ 'Karneval' } & 150 & e & 147 & $\mathrm{c}$ & 166 & $\mathrm{~g}$ & 161 & $\mathrm{f}$ & 86 & $\mathrm{a}$ & 211 & $\mathrm{~h}$ & 148 & $\mathrm{c}$ & 144 & $\mathrm{~b}$ & \multirow{2}{*}{151.6} & \multirow{2}{*}{$\mathrm{a}$} \\
\hline & $a$ & & $\mathrm{~b}$ & & $a$ & & $a$ & & $a$ & & $\mathrm{~b}$ & & $a$ & & $\mathrm{c}$ & & & \\
\hline \multirow{2}{*}{ 'GoldRush' } & 159 & $\mathrm{e}$ & 155 & $\mathrm{~d}$ & 169 & $\mathrm{~g}$ & 165 & $\mathrm{f}$ & 111 & $\mathrm{a}$ & 198 & $\mathrm{~h}$ & 149 & $\mathrm{c}$ & 145 & $\mathrm{~b}$ & \multirow{2}{*}{156.4} & \multirow{2}{*}{$\mathrm{c}$} \\
\hline & $\mathrm{c}$ & & $\mathrm{d}$ & & $\mathrm{b}$ & & $\mathrm{b}$ & & $\mathrm{e}$ & & a & & $\mathrm{a}$ & & c & & & \\
\hline \multirow{2}{*}{ 'Topaz' } & 162 & $\mathrm{e}$ & 158 & $\mathrm{~d}$ & 171 & $\mathrm{~g}$ & 169 & $f$ & 88 & $\mathrm{a}$ & 218 & $\mathrm{~h}$ & 148 & $\mathrm{c}$ & 145 & $\mathrm{~b}$ & \multirow{2}{*}{157.4} & \multirow{2}{*}{ d } \\
\hline & $\mathrm{d}$ & & $\mathrm{e}$ & & $\mathrm{b}$ & & e & & $\mathrm{b}$ & & c & & $a$ & & $\mathrm{c}$ & & & \\
\hline Average & \multicolumn{2}{|c|}{$\frac{1}{164.9}$} & & & & & & & & & & & & & & & & \\
\hline DL5\% & & & & & & & & & & & & & & & & & & \\
\hline
\end{tabular}

Note: values followed by the same letters insignificantly different at $\mathrm{P} \leq 0.05$, according to Duncan's test $5 \%$.

Yellow: the comparison of rootstock influence on studied varieties.

Blue: the comparison of varieties influence on rootstock.

Table 2. Influence of grafting combination on the capacity to form fruit branches at some apple tree varieties in plant nursery

\begin{tabular}{|c|c|c|c|c|c|c|c|c|c|c|c|c|c|c|c|c|c|c|}
\hline Variety & \multicolumn{2}{|c|}{$\begin{array}{c}\mathrm{B} 9 / \mathrm{MM} 111 \\
30 \mathrm{~cm}\end{array}$} & \multicolumn{2}{|c|}{$\begin{array}{c}\mathrm{B} 9 / \mathrm{MM} 111 \\
40 \mathrm{~cm}\end{array}$} & \multicolumn{2}{|c|}{$\begin{array}{l}\mathrm{B} 9 / \mathrm{A} 2 \\
30 \mathrm{~cm}\end{array}$} & \multicolumn{2}{|c|}{$\begin{array}{l}\mathrm{B} 9 / \mathrm{A} 2 \\
40 \mathrm{~cm}\end{array}$} & \multicolumn{2}{|c|}{ Pi80 } & \multicolumn{2}{|c|}{ MM106 } & \multicolumn{2}{|c|}{ M9 } & \multicolumn{2}{|c|}{ B9 } & \multicolumn{2}{|c|}{ Average } \\
\hline \multirow{2}{*}{ 'Pinova' } & 12.2 & $\mathrm{~g}$ & 12.1 & $\mathrm{~g}$ & 10.3 & e & 11.4 & $f$ & 7.6 & $\mathrm{~b}$ & 6.4 & $\bar{a}$ & 8.4 & $\mathrm{c}$ & 9.2 & $\mathrm{~d}$ & \multirow{2}{*}{9.70} & \multirow{2}{*}{ e } \\
\hline & $\mathrm{e}$ & & $\mathrm{e}$ & & $\mathrm{e}$ & & $\mathrm{d}$ & & $\mathrm{f}$ & & $\begin{array}{l}\mathrm{g} \\
\end{array}$ & & $f$ & & $f$ & & & \\
\hline \multirow{2}{*}{ 'Mars' } & 11.5 & $\mathrm{e}$ & 11.7 & $\mathrm{e}$ & 10.3 & $\mathrm{~d}$ & 12.4 & $\mathrm{~h}$ & 8.3 & $\mathrm{~b}$ & 4.2 & $\mathrm{a}$ & 8.2 & $\mathrm{~b}$ & 11.1 & $\mathrm{e}$ & \multirow{2}{*}{9.72} & \multirow{2}{*}{$\mathrm{e}$} \\
\hline & e & & $\mathrm{e}$ & & $\mathrm{e}$ & & e & & $\mathrm{f}$ & & $\mathrm{f}$ & & $\mathrm{f}$ & & $\mathrm{g}$ & & & \\
\hline \multirow{2}{*}{ 'Sirius' } & 13.2 & $f$ & 13.3 & f & 12,2 & e & 13.4 & $f$ & 5.4 & $\mathrm{~b}$ & 3.3 & $\bar{a}$ & 6.1 & $\mathrm{c}$ & 7.2 & $\mathrm{~d}$ & \multirow{2}{*}{9.27} & \multirow{2}{*}{ e } \\
\hline & $\mathrm{g}$ & & $\mathrm{g}$ & & $\mathrm{g}$ & & $f$ & & $\mathrm{e}$ & & $\mathrm{d}$ & & $\mathrm{d}$ & & $\mathrm{d}$ & & & \\
\hline \multirow{2}{*}{ 'Mutsu' } & 3.2 & $\bar{d}$ & 3.3 & $\mathrm{~d}$ & 3.3 & $\bar{d}$ & 2.2 & $\mathrm{~b}$ & 0 & $\bar{a}$ & 2.3 & $\mathrm{~b}$ & 4.2 & $\mathrm{~h}$ & 3.4 & $\bar{d}$ & \multirow{2}{*}{2.74} & \multirow{2}{*}{$\mathrm{a}$} \\
\hline & a & & $\mathrm{a}$ & & $\mathrm{a}$ & & $\mathrm{a}$ & & $\mathrm{a}$ & & c & & c & & c & & & \\
\hline \multirow{2}{*}{ 'Karneval' } & 9.3 & $f$ & 10.5 & $\mathrm{~g}$ & 8.3 & $\mathrm{e}$ & 13.4 & $\mathrm{~h}$ & 3.2 & $\mathrm{a}$ & 3.3 & $\mathrm{a}$ & 5.4 & $\mathrm{c}$ & 6.7 & $\mathrm{~d}$ & \multirow{2}{*}{7.52} & \multirow{2}{*}{$\mathrm{d}$} \\
\hline & $\mathrm{d}$ & & $\mathrm{d}$ & & $\mathrm{d}$ & & $\mathrm{f}$ & & $\mathrm{d}$ & & $\mathrm{d}$ & & d & & $\mathrm{d}$ & & & \\
\hline \multirow{2}{*}{ 'GoldRush' } & 7.3 & $f$ & 7.5 & $\mathrm{f}$ & 6.3 & $\mathrm{e}$ & 8.5 & $\mathrm{~h}$ & 2.2 & $\mathrm{~b}$ & 0.3 & $\mathrm{a}$ & 3.4 & d & 2.1 & $\mathrm{~b}$ & \multirow{2}{*}{4.70} & \multirow{2}{*}{ c } \\
\hline & c & & $\mathrm{c}$ & & c & & c & & c & & $\mathrm{a}$ & & b & & $\mathrm{a}$ & & & \\
\hline \multirow{2}{*}{ 'Topaz' } & 4.4 & $\mathrm{~g}$ & 5.7 & $\mathrm{~h}$ & 3.2 & e & 3.1 & $\mathrm{e}$ & 1.2 & $\mathrm{~b}$ & 0 & $\mathrm{a}$ & 2.2 & $\mathrm{c}$ & 2.1 & c & \multirow{2}{*}{2.74} & \multirow{2}{*}{$\mathrm{a}$} \\
\hline & b & & $\mathrm{b}$ & & $\mathrm{a}$ & & b & & $\mathrm{b}$ & & $\mathrm{a}$ & & $\mathrm{a}$ & & $a$ & & & \\
\hline \multirow{2}{*}{ Average } & & & & & 7.7 & & 9.2 & & & & & & & & & & & \\
\hline & & & & & e & & $\mathrm{g}$ & & & & & & & & & & & \\
\hline
\end{tabular}

Note: values followed by the same letters insignificantly different at $\mathrm{P} \leq 0.05$, according to Duncan's test.

Yellow: the comparison of rootstock influence on studied varieties.

Blue: the comparison of varieties influence on rootstock.

Moreover, more vigorous varieties had the tendency to ramify less. In terms of average values among varieties the highest numbers of branches of fruit were obtained for the trees grafted on 'MM111' with $40 \mathrm{~cm}$ interstem while the trees grafted on 'MM106' formed the lowest number of branches of fruit. In terms of variety the highest number of branches of fruit was formed by the variety 'Sirius' grafted on the rootstock 'MM111' with $40 \mathrm{~cm}$ interstem, 13.5 branches of fruit while for the same combination but with $30 \mathrm{~cm}$ interstem the trees formed 11.3 branches of fruit. More than 10 branches of fruit were also formed by the varieties 'Pinova', 'Mars' and 'Sirius' for the grafting variants with interstem, by 'Mars' on 'B9' and by 'Karneval' for the combinations with $40 \mathrm{~cm}$ interstem.

The length of the interstem did not have a direct influence on the ramification. The average values of the varieties showed that the $40 \mathrm{~cm}$ interstem led to a slightly better ramification on the 'MM111' rootstock while for the rootstock 'A2' the situation was slightly better for the $30 \mathrm{~cm}$ interstem. In terms of variety the situation was different and influenced by the characteristics of that variety. The average values from table 2 has showed the increasing hierarchy of the influence which the grafting combination has had on the capacity to produce fruit branches. buds

\section{Influence of grafting combination on the formation of fruit}

The precocity of the varieties is directly connected to their capacity to form fruit buds as earlier as possible. It is a known fact that precocity is dependent on the variety and that low vigour rootstock influences it but it can also be influenced by using a grafting interstem. The analysis of this parameter for the studied grafting combinations showed different reactions, the 
values being between 0 for the variety 'Mutsu' and 13.5 fruit buds per tree for 'Sirius' grafted on 'MM111' with $40 \mathrm{~cm}$ interstem (Table 3). This parameter was the most influenced by the use of the interstem.

From the comparative analysis of the trees grafted on 'MM106', a rootstock much used in intensive and superintensive orchards, it has been noticed that for four varieties, 'Mutsu', 'Karneval', 'GoldRush' and 'Topaz' there were no fruit buds while for the trees grafted on 'A2' and 'MM111', more vigorous rootstocks, with interstem, between 5.65-6.72 buds per tree were obtained on average, depending on the combination used. At a variety level, for 6 grafting combinations over 10 fruit buds per tree were formed. Very low vigour rootstocks 'M9' and 'B9' which are currently the most used in plant nurseries only influenced the formation of fruit buds at a ratio of $48-59 \%$ compared to the combinations with interstem. It was observed that the variety 'Topaz', a variety currently much appreciated, has not produced buds fruits, except for the combinations with interstem. The average values from Table 2 have showed the increasing hierarchy of the influence which the grafting combination has had on the capacity to produce fruit buds.

Tree height has had a slight negative influence on the capacity of trees to ramify in plant nursery; the dependence between the two parameters highlighted a weak negative influence, the value of the coefficient being small: $\mathrm{r}^{2}=0.098$ (Fig. 1).

The number of fruit branches directly influences the capacity to form fruit buds. For the studied varieties, a tight positive influence was highlighted, the value of the coefficient being of $\mathrm{r}^{2}=0.947$ (Fig. 2).

This dependence is natural due to the fact that fruit buds develop easier in the first years of fructification on branches formed in the same year with the mother branch. These branches usually have large insertion angles in comparison to the support branch which fosters the birth of fruit buds.

Table 3. Influence of grafting combination on the capacity to produce fruit buds at some apple varieties in plant nursery (average number of fruits bud/tree)

\begin{tabular}{|c|c|c|c|c|c|c|c|c|c|c|c|c|c|c|c|c|c|c|}
\hline Variety & \multicolumn{2}{|c|}{$\begin{array}{c}\mathrm{B} 9 / \mathrm{MM} 111 \\
30 \mathrm{~cm}\end{array}$} & \multicolumn{2}{|c|}{$\begin{array}{c}\text { B9/MM111 } \\
40 \mathrm{~cm}\end{array}$} & \multicolumn{2}{|c|}{$\begin{array}{l}\mathrm{B} 9 / \mathrm{A} 2 \\
30 \mathrm{~cm}\end{array}$} & \multicolumn{2}{|c|}{$\begin{array}{l}\mathrm{B} 9 / \mathrm{A} 2 \\
40 \mathrm{~cm}\end{array}$} & \multicolumn{2}{|c|}{ Pi 80} & \multicolumn{2}{|c|}{ MM106 } & \multicolumn{2}{|c|}{ M9 } & \multicolumn{2}{|c|}{ B9 } & \multicolumn{2}{|c|}{ Average } \\
\hline \multirow{2}{*}{ 'Pinova' } & 10.3 & $\mathrm{~h}$ & 9.1 & $\mathrm{f}$ & 9.4 & $\mathrm{~g}$ & 8.3 & $\mathrm{e}$ & 2.2 & $\mathrm{a}$ & 2.1 & $\mathrm{a}$ & 5.3 & $\mathrm{c}$ & 6.2 & $\mathrm{~d}$ & \multirow{2}{*}{6.62} & \multirow[b]{2}{*}{ e } \\
\hline & $\mathrm{e}$ & & $\mathrm{e}$ & & $\mathrm{f}$ & & $\mathrm{e}$ & & $\mathrm{d}$ & & $\mathrm{e}$ & & $\mathrm{f}$ & & $\mathrm{f}$ & & & \\
\hline \multirow{2}{*}{ 'Mars' } & 11.2 & $\mathrm{~h}$ & 9.1 & $\mathrm{e}$ & 10.1 & $\mathrm{f}$ & 10.3 & $\mathrm{~g}$ & 4.4 & $\mathrm{~b}$ & 3.3 & $\mathrm{a}$ & 7.2 & $\bar{c}$ & 7.1 & $\mathrm{c}$ & \multirow{2}{*}{7.84} & \multirow{2}{*}{$\mathrm{g}$} \\
\hline & $f$ & & $\mathrm{e}$ & & $\mathrm{g}$ & & $\mathrm{g}$ & & $\mathrm{g}$ & & $f$ & & $\mathrm{~g}$ & & g & & & \\
\hline \multirow{2}{*}{ 'Sirius' } & 11.3 & $\mathrm{~g}$ & 13.5 & $\mathrm{~h}$ & 7.2 & $\mathrm{e}$ & 9.3 & $\mathrm{f}$ & 2.4 & $\mathrm{a}$ & 3.5 & $\mathrm{~b}$ & 4.2 & $\mathrm{c}$ & 4.3 & $\mathrm{c}$ & \multirow{2}{*}{6.97} & \multirow{2}{*}{$\mathrm{f}$} \\
\hline & $\mathrm{f}$ & & $\mathrm{g}$ & & $\mathrm{d}$ & & $f$ & & $\mathrm{~d}$ & & $f$ & & e & & $\mathrm{e}$ & & & \\
\hline \multirow{2}{*}{ ‘Mutsu' } & 0 & $\mathrm{a}$ & 0 & $\mathrm{a}$ & 0 & $\mathrm{a}$ & 0 & $\mathrm{a}$ & 0 & $\mathrm{a}$ & 0 & $\mathrm{a}$ & 0 & $\mathrm{a}$ & 0 & $\mathrm{a}$ & \multirow{2}{*}{0} & \multirow{2}{*}{$\mathrm{a}$} \\
\hline & $a$ & & $a$ & & $\mathrm{a}$ & & $a$ & & $a$ & & $\mathrm{a}$ & & $\mathrm{a}$ & & $\mathrm{a}$ & & & \\
\hline \multirow{2}{*}{ 'Karneval' } & 7.2 & $\mathrm{e}$ & 7.3 & $\mathrm{e}$ & 7.4 & $\mathrm{e}$ & 7.2 & $\mathrm{e}$ & 2.1 & $\mathrm{~b}$ & 0 & $a$ & 2.3 & $\mathrm{~b}$ & 2.2 & $\mathrm{~b}$ & \multirow{2}{*}{4.47} & \multirow{2}{*}{ d } \\
\hline & $\mathrm{d}$ & & $\mathrm{d}$ & & $\mathrm{d}$ & & $\mathrm{d}$ & & $\mathrm{d}$ & & $\mathrm{a}$ & & $\mathrm{c}$ & & $\mathrm{c}$ & & & \\
\hline \multirow{2}{*}{ 'GoldRush' } & 4.3 & $\mathrm{e}$ & 5.4 & $\mathrm{~h}$ & 4.2 & $\mathrm{e}$ & 4.4 & $\mathrm{e}$ & 1.2 & $\mathrm{~b}$ & 0 & $\mathrm{a}$ & 3.2 & $\mathrm{c}$ & 3.3 & c & \multirow{2}{*}{3.63} & \multirow{2}{*}{ c } \\
\hline & c & & $\mathrm{c}$ & & $\mathrm{c}$ & & $\mathrm{c}$ & & $\mathrm{c}$ & & $\mathrm{a}$ & & $\mathrm{d}$ & & $\mathrm{d}$ & & & \\
\hline \multirow{2}{*}{ ‘Topaz' } & 1.3 & $\mathrm{e}$ & 2.4 & $\mathrm{~h}$ & 1.2 & $\mathrm{e}$ & 1.3 & $\mathrm{e}$ & 0 & $\mathrm{a}$ & 0 & $a$ & 0 & $\mathrm{a}$ & 0 & $\mathrm{a}$ & \multirow{2}{*}{0.78} & \multirow{2}{*}{ b } \\
\hline & $\mathrm{b}$ & & $\mathrm{b}$ & & $\mathrm{b}$ & & $\mathrm{b}$ & & $a$ & & $\mathrm{a}$ & & $a$ & & $a$ & & & \\
\hline \multirow{2}{*}{ Average } & & & & & & & 5.83 & & 1.7 & & & & & & & & & \\
\hline & & & & & & & $\mathrm{f}$ & & $\mathrm{b}$ & & & & & & & & & \\
\hline
\end{tabular}

Note: values followed by the same letters insignificantly different at $\mathrm{P} \leq 0.05$, according to Duncan’s test.

Yellow: the comparison of rootstock influence on studied varieties.

Blue: the comparison of varieties influence on rootstock.

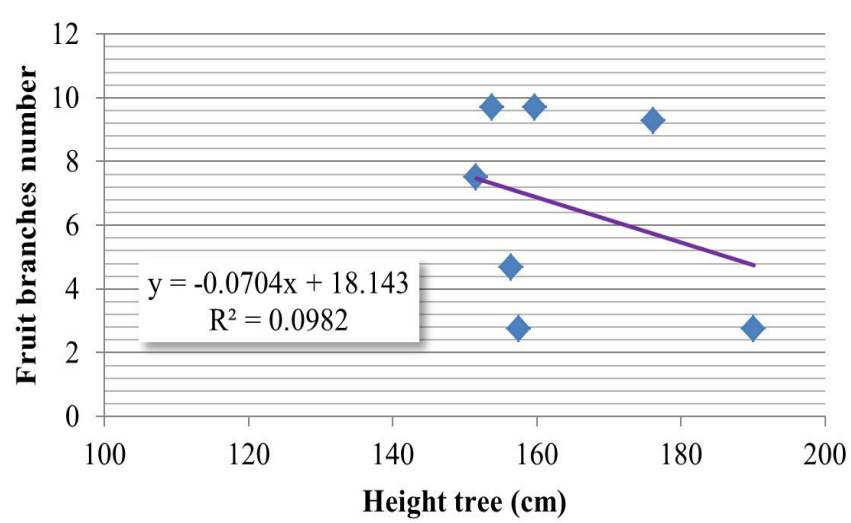

Fig. 1. Dependence between tree height and the capacity to form fruit branches

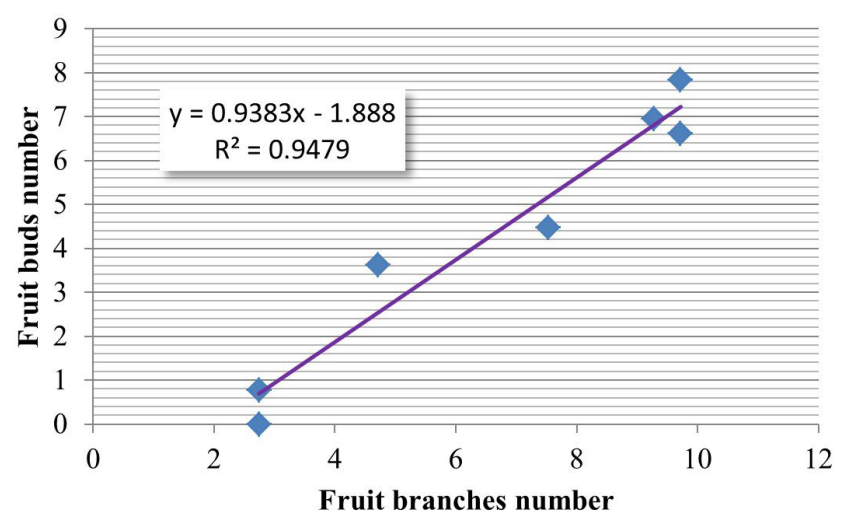

Fig. 2. Dependence between the number of fruit branches and the capacity to form fruit buds 


\section{Conclusions}

The studies conducted highlighted the mutual influence that the variety and the rootstock have on the grafted tree. This influence is given by their genetic characteristics. Depending on the rootstock used the tree has had a different ramification capacity and formed or not in some cases, fruit buds. This feature has influenced the capacity to produce fruits earlier. The use of vigorous rootstocks in combination with the 'M9' interstem provided the grafted trees a good ramification capacity and formed fruit buds. The only exception has been the Mutsu variety which has not formed fruit buds at neither of the grafting combinations. For a good fructification precocity it is recommended the use of grafting combinations with interstem or rootstocks of low vigour such as 'M9' and 'B9' with the varieties 'Pinova', 'Mars' and 'Sirius'. On the other hand, for vigorous tress the combination with the rootstocks 'MM106' and 'A2/B9' can be successful. The genetic features of varieties and rootstocks are important for producing grafting trees and thus they should be taken into consideration.

\section{References}

Atay E, Koyuncu F (2013). A new approach for augmenting branching of nursery trees and its comparison with other methods. Scientia Horticulturae 160:345-350.

Baldini E, Sansavini S (1973). Induction of feathers by growth regulators on maiden trees of apple and pear. Journal of Horticultural Science 48:327337.

Barascu R, Hoza D (2015). Preliminary data regarding the influence of grafting combination on the growth of the graft for the Pinova apple variety.Journal of Horticulture, Forestry and Biotechnology 19(2):1-3.

Basak A, Buban T, Kolodziejczak P (1993). Paturyl 10 wsc as a branching agent for young apple trees in nursery and orchards. Acta Horticulture 329:301-203.

Cimpoies G(2012). Cultura marului. Bons Offices, Chisinau, Moldova.

Cody CA, Larsen FE, Frittes RJr (1985). Stimulation of lateral branch development in tree fruit nursery stock with GA7 + BA. HortScience 20:758-759.

Curry EA (1997). Temperatures for optimum anthocyanin accumulation in apple tissue. Journal of Horticultural Science 72:723-729.

Delgado-Pelayo R, Gallardo-Guerrero L, Hornero-Méndez D (2014). Chlorophyll and carotenoid pigments in the peel and flesh of commercial apple fruit varieties. Food Research International 65(B):272-281.

Di Vaio C, Cirillo C, Buccheri M, Limongelli F (2009). Effect of interstock (M9 and M27) on vegetative growth and yield on apple trees (cv. Anurca).Scientia Horticulturae 119(3):270-274.

Ferree DC, Rhodus WT (1987). Early performance and economic value of feathered apple trees on semi-standard rootstocks. Journal of the American Society for Horticultural Science 112(6):906-909.
Gjamovski V, Kiprijanovski M (2011). Influence of nine dwarfing apple rootstocks on vigour and productivity of apple cultivar 'Granny Smith'. ScientiaHorticulturae 129(4):742-746.

Jakobek L, Barron AR (2016). Ancient apple varieties from Croatia as a source of bioactive polyphenolic compounds. Journal of Food Composition and Analysis 45:9-15.

Johann $G$ (1984). Effect on growth regulators on branching habit of some applecultivars in the nursery. ActaHorticulture 329:35-42.

Karimi HR, Nowrozy M (2017). Effects of rootstock and scion on graft success and vegetative parameters of pomegranate. Scientia Horticulturae 214:280-287.

Lazar V, Sestras A, Mitre V, Sestras R, Mitre I, Ropan G, Barbos A (2010). Variation of sugar content and morphological traits in apple fruit depending on cultivars and fruit exposition in the crown. Bulletin of University of Agricultural Sciences and Veterinary Medicine ClujNapoca. Horticulture 66(1):164-169.

Nagy A, Riczu P, Tamás J (2016). Spectral evaluation of apple fruit ripening and pigment content alteration. Scientia Horticulturae 201:256-264.

Preston AP (1968). Pruning and rootstock as factors in the production of primary branches on apple trees. Journal of Horticultural Science 43:1722.

Rato AE, Agulheiro AC, BarrosoJM, RiquelmeF (2008). Soil and rootstock influence on fruit quality of plums (Prunus domestica L.). Scientia Horticulturae 118(3):218-222.

Samad A, Niel DN, Khan ZU (1999). Effect of interstock bridge grafting (M9, dwarfing and same cultivars cutting) on vegetative, reproductive growth and carbohydrate composition of mature apple trees. Scientia Horticulturae 79(1-2):23-38.

Samouliene G, Viškelienè A, Sirtautas R, Kviklys D (2016). Relationships between apple tree rootstock, crop-load, plant nutritional status and yield. Scientia Horticulturae 211:167-173.

Sestras A, Sestras R, Lazar V, Mitre V, Mitre I, Ropan G, Barbos A (2010). The influence of fruit position in the crown of trees on the sugar content and morphological traits of apple fruits. Bulletin of University of Agricultural Sciences and Veterinary Medicine Cluj-Napoca. Horticulture 66(1).170-176.

Tworkoski T, Miller S (2007). Rootstock effect on growth of apple scion with different growth habits. Scientia Horticulturae 111(4):335-343.

Wertheim SJ (1978). Manual and chemical induction of side shoot formation in apple trees in the nursery. Scientia Horticulturae 9:337345.

Wilson SJ, Jarassamrit N (1994). Nursery factors influencing lateral shoot development in a spur type apple cultivar. Scientia Horticulturae 56(3):207-215. 